\title{
Quantifying climatic variability in monsoonal northern China over the last 2200 years and its role in driving Chinese dynastic changes
}

Jianyong $\mathrm{Li}^{\mathrm{a}}{ }^{*}$, John Dodson ${ }^{\text {a, }}{ }^{*}$, Hong Yan ${ }^{\text {a*, David D. Zhang }}{ }^{\mathrm{c}}$, Xiaojian Zhang ${ }^{\mathrm{d}}$, Qinghai Xu ${ }^{\text {e }}$, Harry F. Lee ${ }^{\text {c }}$, Qing Pei ${ }^{\text {f }}$, Bo Cheng ${ }^{g}$, Chunhai Li ${ }^{\text {h }}$, Jian Ni ${ }^{\text {i }}$, Aizhi Sun ${ }^{\text {j }}$, Fengyan Lu ${ }^{\text {a }}$, Yongqiang Zong ${ }^{\mathrm{k}, \mathrm{l}}$

${ }^{\text {a }}$ State Key Laboratory of Loess and Quaternary Geology, Institute of Earth Environment, Chinese Academy of Sciences, Xi'an 710075 , China. ${ }^{\text {b }}$ School of Biological, Earth and Environmental Sciences, University of New South Wales, Sydney 2033, Australia. ${ }^{\mathbf{c}}$ Department of Geography and International Centre for China Development Study, The University of Hong Kong, Pokfulam Road, Hong Kong, China. ' School of Geographic and Oceanographic Sciences, Nanjing University, Nanjing 210093, China. ${ }^{\mathbf{e}}$ Institute of Nihewan Archaeology, Hebei Normal University, Shijiazhuang 050024, China. ${ }^{\mathbf{f}}$ Department of Social Sciences, The Education University of Hong Kong, 10 Lo Ping Road, Tai Po, New Territories, Hong Kong SAR, China. ${ }^{\mathbf{g}}$ College of Urban and Environmental Sciences, Central China Normal University, Wuhan 430079, China. ${ }^{\mathbf{h}}$ State Key Laboratory of Lake Science and Environment, Nanjing Institute of Geography and Limnology, Chinese Academy of Sciences, Nanjing 210008, China. ${ }^{\text {i }}$ College of Chemistry and Life Sciences, Zhejiang Normal University, Jinhua 321004, China. ${ }^{\mathbf{j}}$ College of Earth Sciences, University of Chinese Academy of Sciences, 19A Yuquan Rd, Shijingshan District, Beijing 100049, China. ${ }^{\mathbf{k}}$ Department of Earth Sciences, The University of Hong Kong, Hong Kong Special Administrative Region, China. ${ }^{\mathbf{I}}$ Guangzhou Institute of Geography, Guangzhou 510070, China 
*Correspondence authors: Jianyong Li (lijy@ieecas.cn), John Dodson (john@ieecas.cn), and Hong Yan (yanhong@ieecas.cn). Address: State Key Laboratory of Loess and Quaternary Geology, Institute of Earth Environment, Chinese Academy of Sciences, Xi'an 710075, China. Telephone number: +86-029-62336270.

\section{Abstract}

Our understanding on the spatial-temporal patterns of climatic variability over the last few millennia in the East Asian monsoon-dominated northern China (NC), and its role at a macro-scale in affecting the prosperity and depression of Chinese dynasties is limited. Quantitative high-resolution, regionally-synthesized palaeoclimatic reconstructions as well as simulations, and numerical analyses of their relationships with various fine-scale, numerical agro-ecological, social-economic, and geo-political historical records during the period of China's history, are presented here for NC. We utilize pollen data together with climate modeling to reconstruct and simulate decadal- to centennial-scale variations in precipitation or temperature for NC during the last 2200 years (-200-2000 AD). We find an overall cyclic-pattern (wet/warm or dry/cold) in the precipitation and temperature anomalies on centennial- to millennial-scale that can be likely considered as a representative for the entire NC by comparison with other related climatic records. We suggest that solar activity may play a key role in driving the climatic fluctuations in NC during the last 22 centuries, with its quasi $\sim 100,50,23$, or 22-year periodicity clearly identified in our climatic reconstructions. We employ variation partitioning and redundancy analysis to quantify the independent effects of climatic factors on accounting for the total variation of 17 fine-grained numerical Chinese historical records. We quantitatively illustrate that precipitation (67.4\%) may 
have been more important than temperature $(32.5 \%)$ in causing the overall agro-ecological and macro-geopolitical shifts in imperial China with $\mathrm{NC}$ as the central ruling region and an agricultural heartland over the last 2200 years.

Keywords: pollen data, northern China, climatic variability, Chinese dynasties

\section{Introduction}

The prosperity and depression of pre-industrial agro-ecological civilizations have been sensitive and subjected to short-term oscillations in water supply, cooling or warming of climate, and land-carrying capacity due partly to abrupt environmental changes (e.g., Haug et al., 2003; Cook et al., 2007; Mann et al., 2009; Buckley et al., 2010; Büntgen et al., 2011; Zhang et al., 2014). Although a growing body of evidence has suggested climate as a possible key driving force for cultural rises and unrests, correlating climatic variations with human historical dynamics is still limited by a lack of high-resolution and macro-scale numerical climatic as well as historical proxy datasets spanning the last few thousand years (e.g., Jones et al., 2009; Büntgen et al., 2011, 2016), especially in regions with a rich source of long-term historical documents such as the northern part of monsoonal China.

The East Asian monsoon (EAM) dominated region in northern China (NC) is a densely populated territory with one of the longest recorded agro-ecological histories of any human civilization in the world, and it embraces an extensive geographic region with various vegetation zones (e.g., Gao et al., 1962; An, 2000; Zhang et al., 2007; Barton et al., 2009; Tan et al., 2011). Ecosystems, vegetation, society, and agriculture in NC are particularly sensitive to rapid climatic variations in monsoonal precipitation as well as temperature that are affected by changes in the strength of summer and winter monsoon in the EAM system (e.g., Zhao et al., 2007; Xu et al., 2010; Li et al., 2015a). NC is 
one of the most important cradles of Chinese civilizations, and cultures that flourished there such as Majiayao, Yangshao, and Dawenkou following the Neolithic period (e.g., An, 1989; Zhang, 2006; Zhang et al., 2008; Tan et al., 2010). Moreover, NC has been the core region of Chinese agro-ecological ruling dynasties, with most capitals established and located in this area from the Qin Dynasty until the Qing Dynasty (e.g., Zhang, 2006; Tan et al., 2010; Zhang et al., 2011). Due to its crucial bio-climatic location as well as important agro-ecological status, robust studies on reliably reconstructing the past climatic variability for NC are therefore needed. Such studies may be of great interest and significance from both scientific and socio-economic perspectives in order to predict the EAM dynamic and its potential influence on society in the future.

Numerous palaeoclimatic reconstructions based on different geological archives and proxy records such as tree rings, lake sediments, speleothems, and historical document analyses have been carried out in NC (e.g., Liu et al., 1996; Peng et al., 2005; Ge et al., 2010; Yang et al., 2014; Tan et al., 2015; Li et al., 2015a). However, there remains a lack of proxy-based, quantitative, high-resolution, and large regional-scale climatic reconstructions covering the whole region of $\mathrm{NC}$ over the last few millennia (e.g., Yang et al., 2002; Wang et al., 2007; Ge at al., 2013). Moreover, there exist marked discrepancies among the limited number of previous large-scale palaeoclimatic reconstructions with regards to high- or low-frequency characteristics, spatial-temporal patterns, and underlying driving factors of the EAM evolution in NC. Likewise, as a matter of fact, these earlier palaeoclimatic datasets could not clearly differentiate the signal of precipitation from that of temperature, thus leading to the scarcity of high-quality twin-datasets including the signals of both precipitation and temperature in $\mathrm{NC}$, which further hinder a precise evaluation of the forcing mechanisms in driving 
past climatic changes in this region. As a consequence, quantitative characteristics and mechanisms of decadal- to centennial-scale climatic variations in the monsoonal precipitation as well as temperature for the entire NC during Chinese historical times especially the last 2200 years are still not fully understood. In addition, quantitative effects of individual climatic factors and their joint effects on independently accounting for how much of the variation in the rise and fall of Chinese dynasties have so far not been yet unambiguously assessed. This would likely impede an accurate assessment for the relative roles of both precipitation and temperature in affecting the long-standing human historical changes in NC.

Biological proxies such as pollen and chironomid spectra taken from lake sediment cores are one of the most important sources for reliably producing quantitative terrestrial palaeoclimatic data on various spatial and temporal scales (e.g., Birks, 1998; Seppä et al., 2004; Birks et al., 2010). Use of robust and accurate numerical reconstruction approaches from well-designed, continental-scale, and organism-based calibration databases has been demonstrated to be an effective method for large-scale integrated, fossil-based quantitative palaeoclimatic estimates in various regions of the world (e.g., Davis et al., 2003; Viau et al., 2006; Seppä et al., 2009; Bartlein et al., 2011; Salonen et al., 2014; Heiri et al., 2014). Additionally, because of improvement in chronological control and increased spatial-temporal resolution in numerous site-specific reconstructions, it is now realistic and feasible to synthesize these data for obtaining regional-scale and quantitatively-composited palaeoclimatic datasets, so as to better understand details of the geographically-coherent climatic variability over the last several centuries to thousand years (e.g., Viau et al., 2006; Renssen et al., 2009; Seppä et al., 2009; Jin et al., 2014; Li et al., 2015a). 
Here we firstly develop robust pollen-based calibration models for annual mean precipitation (PANN) and annual mean temperature (TANN) based on the high-quality Chinese surface pollen-climate database (Zheng et al., 2014; Li et al., 2015b), and then apply these models to five high-resolution fossil pollen sequences from lake sediment cores in different parts of NC to generate ten new climatic reconstructions for the last 2200 years, on the basis of the well-accepted assumption that broad-scale pollen datasets from lake sediments can likely represent regional vegetation as well as climatic signals (e.g., Seppä et al., 2004; Zhao et al., 2009a; Birks et al., 2010). Secondly, we stack these reconstructions together with twelve earlier pollen-based climatic reconstructions to provide a dataset consisting of both PANN and TANN records for NC. We further compare them with a PANN simulation from a coupled atmosphere-ocean-sea ice general circulation model (the Kiel Climate Model, $\mathrm{KCM}$ ) and other proxy-based climatic records for investigating regional patterns, potential periodicities, and underlying mechanisms of the climatic history in NC. Thirdly, we assemble seventeen previously-published and fine-grained numerical historical records which cover various agro-ecological, demographic, socio-economic, and geo-political variables during the course of Chinese Dynasties from the Han to Qing Dynasty (-200-2000 AD). Finally, we employ statistical techniques including variation partitioning and redundancy analysis for evaluating quantitatively the relationships between climatic variability and Chinese dynastical change for the last 2200 years in northern China.

\section{Study area}

The area under this study is the northern part of monsoonal China where the climate has been primarily dominated by the East Asian monsoon circulation during the late Holocene (e.g., Feng et 
al., 2006; Tan et al., 2011; Ran and Feng, 2013; Chen et al., 2015a; Liu et al., 2015). This area geographically covers the EAM-affected regions of northeastern China, central and eastern Inner Mongolia, the Loess Plateau, and the northeastern Qinghai-Tibetan Plateau (Fig. 1 and Fig. S1). It particularly spans a large-scale climatic gradient for both rainfall and temperature, with annual mean precipitation from above $600 \mathrm{~mm}$ in the southeast to below $100 \mathrm{~mm}$ in the northwest, and annual mean temperature from over $5{ }^{\circ} \mathrm{C}$ in the south to under $0{ }^{\circ} \mathrm{C}$ in the north (e.g., Ran and Feng, 2013; Li et al., 2014, 2015b). It naturally embraces several vegetation types varying from the northeast to the southwest, including cold temperate conifer forest, temperate mixed conifer and deciduous forest, warm temperate deciduous forest, and temperate steppe (e.g., Hou, 2001; Ren and Beug, 2002). It has been demonstrated to be the core region of Chinese dynasty, agriculture, economy, and settlement over the last 3000 years, as clearly indicated by a high number of both historical documents and archaeological studies (e.g., Zhao and Xie, 1988; Shi, 1991; Zhu, 1992; Fang and Xie, 1994; Ren, 2000). As a result, most of the natural plant ecosystems in monsoonal northern China have been disturbed by human activities, especially in the highly populated low-land or plain areas where various cultivated fields occur as the dominant landscape type at present (e.g., Zhu, 1994; Ren, 2000). However, the relatively natural vegetation systems, such as forests only exist fragmentally in some remote or high mountainous regions such as Daxingan, Xiaoxingan, Changbai, Taihang, Yin, and Qilian Mountains; and patchy steppes distribute separately in the less populated Inner Mongolian and Qinghai-Tibetan Plateaus (e.g., Chen and Wang, 1999; Ren and Beug, 2002; Li et al., 2014). Correspondingly, herein the studied sites were suitably selected from these aforementioned mountainous or plateau domains with as low human influence as possible in order to best avoid 
misleading results (e.g., Sun and Feng, 2013; Chen et al., 2015a; Stebich et al., 2015). Further, the reliability of our pollen-based climatic reconstructions was also critically validated by model-based climatic transient simulations and other multi-proxy-synthesized moisture or temperature records from both northern China and northern Hemisphere. In addition, surface pollen samples used for constructing our calibration models were indeed collected to largely reflect the natural vegetation, omitting the sites with a signal of strong local human impact (e.g., Li et al., 2007). Moreover, Li et al. (2014) has statistically demonstrated that the effect of human influence index (HII) on the Chinese pollen-climate dataset as a whole is minor in comparison with PANN and TANN when independently accounting for the total variation of modern pollen distribution. Likewise, many earlier studies in Europe and North America have shown that at a large regional- to continental-scale, modern pollen distribution is regarded as a result of natural climatic controls and that the relationship between modern vegetation and climate is either statistically or ecologically significant (e.g., Huntley and Prentice, 1988; Cheddadi et al., 1997; Davis et al., 2003; Bartlein et al., 2011; Peyron et al., 2011; Mauri et al., 2015). Taken together, it is likely that both modern and fossil pollen datasets selected in our study area may be reliable for quantitative climatic estimates during the last few thousand years.

\section{Materials and Methods}

\subsection{Pollen-based climatic reconstructions}

Pollen-based quantitative reconstructions for both PANN and TANN were prepared from eleven fossil pollen stratigraphies from lake sediment cores in the northern region of monsoonal China (Fig. 
1 and Fig. S1), where more than $80 \%$ of the annual rainfall falls during the summer-monsoonal season, which is also associated with the highest temperature over the whole of the year (e.g., Gao et al., 1962; Zhao et al., 2009b). In this study, PANN and TANN were taken into consideration, because they are considered as important bioclimatic variables for plant distribution and have been most frequently employed for modern pollen-climate studies or pollen-based numerical climatic inferences in northern China (e.g., Guiot et al., 2008; Herzschuh et al., 2009; Xu et al., 2010; Li et al., 2014, 2015b). This allows us to synthesize a high number of previously-published PANN and TANN records in northern China, together with our newly-obtained reconstructions, making it possible to provide the regionally-averaged and geographically-coherent records for PANN and TANN over the last 2200 years. More importantly, it is feasible and realistic that such pollen-composited PANN and TANN records can be explicitly assessed by other proxy-based or model-simulated PANN or TANN records in both northern China and northern Hemisphere. Additionally, the fossil pollen sites selected here ideally cover the macro-scale climatic gradients over the entire monsoonal area of northern China. Such fossil records were chosen based on five criteria: (1) under the strong influence of EAM; (2) reliable chronological control with at least 7 dating points (except for Chasuqi with 4 dates); (3) high mean temporal resolution with at least 90 years between samples (except for Bayanchagan with 130 years resolution); (4) continuous sequence with no evident sedimentary hiatus (except for Bayanchagan); and (5) relatively low human impact in surrounding regions of the sampled site (see Table S1 for references and other details). These criteria have been widely used for the regionally-composited and proxy-based palaeoclimatic reconstructions in northern China (e.g., Zhao et al., 2009b; Ran and Feng, 2013; Liu et al., 2015; Li 
et al., 2015b). All geochronological sequences were based on the AMS radiocarbon dating method (Tables S1 and S2). All ages were calibrated to calendar years using the INTECAL calibration datasets (Table S2) (e.g., Reimer et al., 2004, 2009, 2013). Various bulk sediments, organic matters, total organic carbons, peats, and plant remains or macrofossils were employed for the ${ }^{14} \mathrm{C}$ dating measurements (e.g., Xu et al., 2010; Sun and Feng, 2013; Chen et al., 2015a; Stebich et al., 2015). To attain a consistent chronological framework, the age-depth models of all fossil records from lake sediment cores were estimated by utilizing a linear regression, interpolation, or extrapolation between adjacent dates according to the published data, and the old carbon effects were corrected for the ${ }^{14} \mathrm{C}$ dates based on the dated surface sediment samples if necessary (e.g., Shen et al., 2005; Jiang et al., 2006; Cheng et al., 2013; Sun and Feng, 2013). Most of the fossil pollen records were published since 2000 AD (e.g., Liu et al., 2002; Jiang et al., 2006; Xu et al., 2010; Sun and Feng, 2013; Chen et al., 2015a).

The calibration models for quantitative climatic reconstructions were based on the continental-scale Chinese surface pollen-climate database which has been described in detail elsewhere (Zheng et al., 2014; Li et al., 2015b). Weighted-averaging partial least squares (WA-PLS) regression (ter Braak and Juggins, 1993) was utilized to construct the calibration models for both PANN and TANN. The pollen percentage values of all terrestrial taxa were transformed to square-roots for optimizing the "signal" to "noise" ratio and for stabilizing the variances (Prentice, 1980). The WA-PLS technique was selected as it has been commonly used in many studies and has been proved to perform as well as or even more robust in comparison with other calibration techniques for the pollen-based numerical climatic reconstructions (e.g., Birks, 1995; Seppä et al., 
2004, 2009; Birks et al., 2010; Li et al., 2015a). Model performance was assessed using leave-one-out cross-validation (Birks et al., 1990). Performance statistics were measured by calculating coefficient of determination $\left(\mathrm{R}^{2}\right)$ between observed and forecasted values, root-mean-square error of prediction (RMSEP), as well as maximum bias. The two-component WA-PLS models for both PANN and TANN were chosen according to high $\mathrm{R}^{2}$, low RMSEP or maximum bias, and the lowest number of useful components (Birks, 1998). All model evaluations and climatic reconstructions were done with the C2 software (Juggins, 2007). In order to synthesize the common climatic signals as well as highlight the regionally consistent patterns, each PANN or TANN reconstruction was first expressed as deviations (departures or anomalies) from the average of that reconstruction over the last 2200 years. Hence the tool of pivot table in Excel was utilized to summarize all PANN or TANN departures in a concise and consistent format. The departures with a same age were averaged to one mean value, whereas the departures with a different age were assembled in sequence based on the unified chronological order. In this way, two high-resolution and regionally-stacked climatic series (PANN and TANN) were yielded for NC during the last 2200 years. Such a stacking methodology has been successfully employed in many earlier pollen-based climatic inferences at a large regional scale from different areas of the world (e.g., Viau et al., 2006; Seppä et al., 2009; Salonen et al., 2014; Mauri et al. 2015; Li et al., 2015a). To clearly highlight the high-frequency climatic oscillations at decadal- to centennial-scale (e.g., Davis et al., 2003; Viau et al., 2006; Seppä et al., 2009; Xu et al., 2014), the integrated curves for both PANN and TANN were detrended using polynomial fitting and then were 15-point smoothed. Spectral analyses for climatic periodicities of PANN and TANN records were carried out with the Redfit software (Schulz and 
Mudelsee, 2002). The Redfit software is capable of handling unevenly spaced data with respect to palaeoclimatic time series, and testing significance in the spectrum peaks against the red-noise background with a null-hypothesis, which can be evaluated by utilizing the first-order autoregressive signals, where characteristic time-scales as well as sampled time-spans match those of the tested palaeoclimatic data with no requirements for any interpolation (Schulz and Mudelsee, 2002).

\subsection{KCM simulation experiments}

The PANN variations in monsoonal northern China covering the last 2200 years were also simulated by a coupled atmosphere-ocean-sea ice general circulation model, the Kiel Climate Model (KCM; Park et al., 2009). The KCM model consists of the European Centre for Medium-Range Weather Forecasts (ECMWF) Hamburg atmospheric general circulation model version 5 (ECHAM5; Roeckner et al., 2003) and the Nucleus for European Modelling of the Ocean (NEMO; Madec, 2008) ocean-sea ice general circulation model, with the Ocean Atmosphere Sea Ice Soil version 3 (OASIS3; Valcke, 2006). The spatial resolution of the KCM model is $\mathrm{T} 31\left(3.75^{\circ} \times 3.75^{\circ}\right)$ with 19 vertical levels. Concentrations of the greenhouse gases in the atmosphere of the simulation were set to the levels of period prior to the industrial era. The orbital parameters (Berger and Loutre, 1991) were varying for the simulation period with a 10-times acceleration scheme (Lorenz and Lohmann, 2004). The simulated PANN for the area at $100-130{ }^{\circ} \mathrm{E}$ and at $35-50{ }^{\circ} \mathrm{N}$ were extracted for representing the high-resolution PANN variability for monsoonal northern China over the last 2200 years.

\subsection{Variation partitioning and redundancy analysis}


Variation partitioning (Borcard et al., 1992) was used for quantifying the independent effects of PANN or TANN and their shared effects on explaining the total variation of the seventeen numerical historical indices that were derived from many previous publications. These historical data were produced by integrating a large number of Chinese historical documents and have been mostly published after 2000 AD (see Table S3 for references and details). Redundancy analysis (RDA; ter Braak and Šmilauer, 2002) was used for evaluating the general patterns of the associations among the integrated PANN or TANN records and the seventeen numerical historical records. Monte Carlo permutation tests involving 999 permutations were performed for assessing the statistical significance of the climatic variables (PANN and TANN). All analyses were implemented with the Canoco 5 software (ter Braak and Šmilauer, 2012).

\section{Results and discussion}

\subsection{Variations in precipitation and temperature in northern China over the last 2200 years}

Leave-one-out cross-validated performance statistics of the two pollen-based calibration models for PANN and TANN are presented in Figure S2. Overall statistical performance is robust for both models, with high $\mathrm{R}^{2}$ (0.84 for PANN and 0.71 for TANN) and low RMSEP (232.06 mm for PANN and $3.62{ }^{\circ} \mathrm{C}$ for TANN). The original pollen-integrated reconstructions for PANN $( \pm 232.1 \mathrm{~mm})$ or TANN $\left( \pm 3.6^{\circ} \mathrm{C}\right.$ ) based on 22 site-specific reconstructions from 11 fossil pollen sequences in NC are shown in Figure S3. The detrended, smoothed PANN and TANN records are provided in Figures 2 and 3, respectively. From the viewpoint of centennial-scale changes, the pollen-stacked PANN record (-200-2000 AD) for NC shows six noteworthy humid intervals (-200-100, 241-440, 561-840, 
1101-1320, 1741-1820, and 1921-2000 AD) and five remarkable dry intervals (101-240, 441-560, 841-1100, 1321-1740, and 1821-1920 AD) (Fig. 2). Eight decadal-scale droughts can be observed at around 190, 510, 700, 1000, 1380, 1500, 1660, and 1840 AD. In general, our pollen-reconstructed PANN record shares broad low-frequency similarities with our coupled KCM-simulated decadal-scale PANN record for $\mathrm{NC}\left(100-130^{\circ} \mathrm{E}\right.$ and $\left.35-50{ }^{\circ} \mathrm{N}\right)$, as well as other high-resolution EAM moisture records from NC, Korea, and Japan (Fig. 2). These moisture-related records comprise the regionally-synthesized precipitation index for north-central China (Tan et al., 2011), the $\delta^{18} \mathrm{O}$ records from Wanxiang Cave (Zhang et al., 2008) and Huangye Cave (Tan et al., 2010) on the western Loess Plateau, the regional dry/wet index based on historical documents for the northern China Plain (Zheng et al., 2006), the coupled ECHO-G simulated precipitation for northern China during summertime from May to August (Liu et al., 2011), the reconstructed drought index from Korea (Kim and Choi, 1987), and the $\delta^{18} \mathrm{O}$ record from Fukugaguchi Cave interpreted as a proxy for winter precipitation in Japan (Sone et al., 2013) (Fig. 2). However, some of the most remarkable eight high-frequency drought events seen in our PANN record are not clearly identified in the other aforementioned EAM moisture records.

With respect to the temperature changes in NC, the pollen-integrated TANN record (-200-2000 AD) reveals four marked warm periods (-200-120, 640-760, 901-1300, and 1901-2000 AD) and three apparent cold periods (121-639, 761-900, and 1301-1900 AD) (Fig. 3). Six conspicuous decade-scale cool climatic events are revealed at around 420, 590, 800, 1640, 1740, and 1860 AD. By comparison with the composited temperature record for entire China (Ge et al., 2013), the winter half-year temperature for central-eastern China (Ge et al., 2003), the temperature reconstruction of 
monsoonal warm-season from May to August based on thickness variations of a stalagmite from Shihua Cave in NC (Tan et al., 2003), as well as the three integrated temperature series for northern Hemisphere (NH) as a whole (Ljungqvist, 2010; Christiansen and Ljungqvist, 2012; Kobashi et al., 2013), we recognize that the overall low-frequency trends and some of the high-frequency cooling events correspond well among these temperature sequences (Fig. 3). Similar results have been acquired by studies from north-central China (Tan et al., 2011) and tree rings in the Dulan area on the north-eastern Tibetan Plateau (Liu et al., 2006). However, a remarkable warm epoch in NC over the period of about 580-760 AD is not notably reflected in the $\mathrm{NH}$ temperature series. The foregoing discrepancies among different precipitation or temperature records at a large regional-scale may be resulted from the differences in various reconstruction techniques, diverse proxy indicators, and inconsistent spatial-temporal resolutions of the original individual records used (e.g., Yang et al., 2002; Wang et al., 2007; Cook et al., 2010; Ge et al., 2013).

In summary, our stacked PANN and TANN curves for NC mostly exhibit concurrent patterns over the last 2200 years. Taking the last millennium as an example, both PANN and TANN show higher values during the Medieval Climate Anomaly (MCA), lower values during the Little Ice Age (LIA), and higher values again during the Current Warm Period (CWP). Taken together, the above comparisons suggest that our stacked climatic reconstructions portray well the details and overall trends of the long-term variations in the monsoonal precipitation as well as temperature for northern China over the last 22 centuries.

\subsection{Possible driving forces of climatic changes in northern China over the last 2200 years}

It has been widely suggested from both climate modeling and observation data that solar activity 
plays a key role in driving late-Holocene climatic fluctuations by triggering global temperature variability and atmospheric dynamical circulation (e.g., Haigh, 1996; Shindell et al., 1999; Bond et al., 2001; Fleitmann et al., 2003; Dykoski et al., 2005). Spectral analyses indicate that the PANN record has significant periodicities at 100, 67, 57 and 23 years; and the TANN record displays notable periodicities at 118, 103, 80, 67, 56, 50, 40 and 22 years (Fig. 4). The 100, 57 and 23 year periods for PANN, as well as the 103, 50, and 22 year periods for TANN, correlate well with the 100, 50, 23 and 22 year cycles for the solar activity observed in various solar parameters (e.g., Wilson et al., 1996; Li et al., 1996; Chowdhury et al., 2009; Zhao et al., 2014), therefore implying an in-phase relationship between the climatic oscillation in NC and solar activity. Furthermore, a multi-decadal to centennial comparison of our pollen-derived TANN reconstruction for NC with the Total Solar Irradiance (TSI; Vieira et al, 2011), the Asian Pacific Oscillation index (APO; Zhou et al., 2009), the Intertropical Convergence Zone index (ITCZ; Haug et al., 2001), the North Atlantic Oscillation index (NAO; Trouet et al., 2009; Olsen et al., 2012) and the Ice-Rafted Debris record (IRD; Bond et al., 2001) from the North Atlantic Ocean, suggests a strong underlying teleconnection between the EAM regime in NC and many other high- or low-latitude climatic systems in different regions of the northern Hemisphere (Fig. 3).

In short, the mechanism of the climatic variations in NC can be likely summarized as follows. The strengthened solar activity could be significantly amplified by the variations in ultraviolet radiation as well as clouds (e.g., Haigh, 1996; Tinsley, 2000), resulting in the marked variability in global surface temperature. As the heat capacity between land and ocean differs notably, if TSI increases, the thermal contrast between the East Asian continent and the North Pacific Ocean would be 
enhanced, resulting in high values of APO and thus northward shift of both ITCZ and Western Pacific Subtropical High (WPSH) positions (e.g., Zhao et al., 2007; Zhou et al., 2009), so that the summer monsoon and its rain belt would move further north and stay longer in NC. At the same time, because the increased TSI would lead to decreased IRD values, but increased North Atlantic Deep Water (NADW) circulation, and hence a positive NAO phase, the EAM continent including $\mathrm{NC}$ would receive less cold air masses from the high-latitude regions of $\mathrm{NH}$ and thus be substantially warming up, so that the winter monsoon and westerlies would be concurrently weakened and retreat northward (e.g., Wu and Wang, 2002; Wang et al., 2005; Li et al., 2015a). As a result, the enhanced summer monsoon would bring more rainfall to $\mathrm{NC}$ where the surface temperature is also synchronously higher. In contrast, when TSI declines, the EAM land temperature falls quickly, whereas the winter monsoon and westerlies would be intensified, thus leading to increased IRD values, but declining NADW strength as well as a negative NAO phase; and meanwhile the positions of both ITCZ and WPSH would retreat southward, the summer monsoon intensity would be significantly weakened, thereby resulting in the coincidently decreased precipitation as well as temperature in NC. Additionally, increased El Niño-Southern Oscillation (ENSO) strength (possibly El Nińo-like phases) during drying periods, increased volcanic eruptions and the resulting aerosol load during cooling periods, as well as high volumes of greenhouse gases such as $\mathrm{CO}_{2}$ and $\mathrm{CH}_{4}$ during the recent warming periods, may also play a role in partly affecting the climatic variability in NC, superimposing on the overall solar-dominated long-term control (e.g., Wanner et al., 2008; Tan et al., 2011; Kobashi et al., 2013; Chen at al., 2015a, b).

\subsection{Quantitative relationships between climatic variations and Chinese dynastical changes}


To the best of our knowledge, variation partitioning results obtained here, for the first time, quantitatively illustrate that when independently accounting for the total variation in 17 Chinese numerical historical indices (Fig. 5 and Table S3), including economic level (EL), grain yield grade (GY), grain price index (GPI), fiscal grade (FG), agriculturalist policy territory (AT), extreme flood years $(\mathrm{EF})$, extreme drought years (ED), freeze disaster frequency (FD), sand-dust event frequency (SD), famine index (FI), locust frequency (LF), epidemic disaster frequency (EPD), peasant uprising frequency (PUF), number of wars (NW), number of southward nomadic migrations (SNW), farming-pastoral boundary (FPB), and number of estimated human population (HP), the importance of PANN (67.4\%) is much higher than that of TANN (32.5\%) as well as that of their shared effects $(0.1 \%)$; and moreover, both PANN and TANN together with their interactions have a highly statistically significant $(p=0.01)$ relationship with all of the 17 historical indices (Fig. 6). Results of the RDA analysis show that GY, HP, PFB, AT and SD are positively associated with PANN, while ED and NW are negatively associated with PANN; and that GPI, EI, FG, EF, EPD and FI are positively correlated to TANN, whereas FD, SNM and LF are negatively correlated to TANN (Fig. 6). These results suggest that in fact precipitation seems likely to be more important than temperature in driving the overall macro-scale agro-ecological, geo-political, and bio-ecological shifts in imperial China with $\mathrm{NC}$ as the main governing region and an important agricultural heartland over the last 2200 years.

Generally speaking, the downturns of most Chinese agro-ecological dynasties in NC such as the West Han, East Han, 5D \& 10K (the era of Five Dynasties and Ten Kingdoms), Yuan, and Qing Dynasties, were mostly caused by armed conflicts with the northern pastoral polities or large-scale 
famines and peasant uprisings within these dynasties, which often took place at notable dry episodes that corresponded to low values of GY, HP, GL, and FG, but high values of RPI, EF, ED, FI, LI, PUF, and NW (Fig. 5). In contrast, the depressions of some agro-ecological dynasties such as the Sui, North Song, and Ming Dynasties closely correlated with less drier but cold periods; and whereas the downfalls of other dynasties such as the Tang Dynasty has been suggested to be mainly resulted from internal political struggles with climatic change as a minor contributing factor (Zhang et al., 2007, 2010, 2014). The former is probably due to the NC dry-winter monsoon being more influential in arid periods, whilst moist-summer monsoon dominated in wet intervals, leading to higher terrestrial bio-productivity and land-carrying capacity in this area, since they are more sensitive to the variations in water supply. The steppe ecosystems exploited by the grass-fed nomadic societies (e.g., Hsiung-nu, Hsien-pi, Türk, Khitan, Tangut, Mongol, Oirat, and Jurchen) from Mongolia and its surrounding regions indeed surfer most from food shortages in severe droughts, and thus tend to invade the southern agricultural areas and to migrate the peripheral sedentary territories and plunder for subsistence (e.g., Zhang et al., 2014; Büntgen et al., 2016). Such a drought-induced or nomad-triggered demise of the ancient agro-ecological civilizations has also occurred in Middle East (e.g., Mesopotamia and Turkey), North Africa (e.g., Egypt and Tunisia), and North America (e.g., Pueblo and Mississippi) (e.g., Issar, 1995; Weiss and Bradley, 2001; Enzel et al., 2003; Cook et al., 2007; Zhang et al., 2011). In comparison, the effect of water supply may be relatively smaller in tropical or subtropical humid as well as cool humid areas, such as South China and West Europe where the land-carrying productivity is comparatively higher, so that the cooling effect of climate may be more detrimental in driving upturns and downturns of the pre-industrial agro-ecological 
civilizations in these regions (e.g., Zhang et al., 2007, 2011). This suggests that the response of human agro-ecological civilizations to the climatic change varies geographically, because of differences in their food diversity, ecological vulnerability, and adaptive capacity. Such close match-up, rhythmic process, and causal relationship are likely not accidental, but have been suggested as a generalized push-pull phenomenon or a resultant outbreak of Malthusian checks during the pre-industrial era (e.g., Zhang et al., 2007, 2011, 2014; Büntgen et al., 2016). In addition, our findings do not contradict earlier theories with regards to the individuality as well as complexity of the geo-political shifts in human history. In this regard, more detailed case-by-case studies are needed and would thereof further improve our understanding of the past or future climatic as well as environmental circumstances under which the momentous societal events have taken place at the macro-geographical scale on the long-term time series.

While climatic shifts may be a trigger to the eco-political changes it is the socio-economic and political response which ring in the scales of the changes. The resilience of societies to changes depends on the strength of their institutional structures, geographical locations, and the technology, leadership and cultural setting. Hardship brought on by challenging environments can be managed in some circumstances but where this threatens livelihoods and institutional structures then this can be a trigger leading to historical changes, even at dynastic levels (e.g., Zhang et al., 2007, 2011). The environmental records reveal much smaller scale variability within the timing of major dynasties, and clearly these were managed successfully. In this aspect, the need for more case studies outlined above is likely to be a fruitful area of research in identifying the environment-society interactions which lead to tipping points. 


\section{Conclusions}

In the present study, we synthesize a set of 22 pollen-estimated quantitative records for PANN and TANN from 11 sites in the East Asian monsoon-influenced region of northern China to contribute two high-resolution records for precipitation and temperature spanning the last 2200 years for this large geographical region. The overall patterns of pollen-synthesized PANN record are in agreement with a decadal- to centennial-scale PANN simulation for the northern territory of monsoonal China based on the KCM coupled climate model. The pollen-composited PANN or TANN sequence for NC is generally in line with other proxy-synthesized or model-based individual moisture or temperature records from the EAM-dominated temperate Asia or northern Hemisphere. This broad-scale positive correlation suggests that the PANN or TANN record derived from pollen data can be probably regarded as a representative for NC as a whole. In addition, the synthesized PANN and TANN curves for NC mostly display coincident trends on multi-centennial to millennium time-scale during the last 2200 years.

The inter-regional multi-proxy comparison of our composite PANN and TANN reconstructions with TSI and other related high- or low-latitude competing climatic driving forces suggests a possible underlying teleconnection between the EAM system of NC and other large-scale terrestrial or oceanic climatic circulations across the northern Hemisphere. Solar activity may be considered as the dominant force driving the overall in-phase changes of monsoonal precipitation as well as temperature at centennial- to millennium-scale by modulating the EAM system through controlling the thermal contrast between the eastern Asian continent and the northwestern Pacific Ocean. Other forcing factors such as NAO, WPSH, and ITCZ may also play a role in partly affecting the climatic 
variability in $\mathrm{NC}$, superimposing on the overall solar-dominated long-term control.

The statistical analyses indicate that both PANN and TANN along with their interactions may have a highly significant relationship with the variation of 17 numerical Chinese historical records consisting of various agro-ecological, socio-economic, and geopolitical variables. The variation partitioning results firstly demonstrate that PANN is more important than TANN in independently accounting for the total variation in the comprehensive Chinese historical dataset assembled in this study. This suggests that in reality precipitation may play a more important role compared with temperature for affecting the dynastic changes in pre-industrial imperial China with $\mathrm{NC}$ as a major governing territory and a crucial agricultural heartland during the last 2200 years.

It is likely that additional high-resolution, large-scale precipitation and temperature datasets based on various geological proxies and coupled climate models are needed in order to further understand the spatial and temporal patterns of climatic variability and its mechanism in different regions of monsoonal China over the last few millennia. In addition, more efforts are also probably required to further investigate the numerical relationships between climatic fluctuations and human historical dynamics at a wide range of temporal and spatial scales during the pre-industrial period of China.

\section{Acknowledgments}

This work was financially funded by projects from the State Key Laboratory of Loess and Quaternary Geology in the Institute of Earth Environment of the Chinese Academy of Sciences (Y652001589 and Y651031589), the West Light Foundation of The Chinese Academy of Sciences (XAB2016B01), the National Science Foundation of China (NSFC) (41522305 and 41403018), the 
Major State Basic Research Development Program of China (973 Program) (2013CB955900), and the Chinese Academy of Sciences (QYZDB-SSW-DQC001, 132B61KYSB20160003, and 55ZZBS1304101).

\section{References}

An, Z.M., 1989. Prehistoric agriculture in China. In: Harris, D.R., Hillman, G.C. (Eds.), Foraging and Farming: the Evolution of Plant Exploitation. Unwin Hyman Press, London, pp. 643-649.

An, Z.S., 2000. The history and variability of the East Asian paleomonsoon climate. Quat. Sci. Rev. 19, 171-187.

Bartlein, P.J., Harrison, S.P., Brewer, S., Connor, S., Davis, B.A.S., Gajewski, K., Guiot, J., Harrison-Prentice, T.I., Henderson, A., Peyron, O., Prentice, I.C., Scholze, M., Seppä, H., Shuman, B., Sugita, S., Thompson, R.S., Viau, A.E., Williams, J., Wu, H., 2011. Pollen-based continental climate reconstructions at 6 and 21 ka: a global synthesis. Clim. Dyn. 37, 775-802.

Barton, L., Newsome, S.D., Chen, F.H., Wang, H., Guilderson, T.P., Bettinger, R.L., 2009. Agricultural origins and the isotopic identity of domestication in northern China. Proc. Natl. Acad. Sci. USA 106, 5523-5528.

Berger, A., Loutre, M.F., 1991. Insolation values for the climate of the last 10 million years. Quat. Sci. Rev. 10, 297-317.

Birks, H.J.B., 1995. Quantitative palaeoenvironmental reconstructions, in: Statistical modeling of Quaternary science data, Technical Guide 5, edited by: Maddy, D. and Brew, J. S., Quaternary Research Association, Cambridge, pp. 161-254.

Birks, H.J.B., 1998. Numerical tools in quantitative palaeolimnology - progress, potentialities, and 
problems. J. Paleolimnol. 20, 301-332.

Birks, H.J.B., Heiri, O., Seppä, H., Bjune, A.E., 2010. Strengths and weaknesses of quantitative climate reconstructions based on late-Quaternary biological proxies. Open. Ecol. J. 3, 68-110.

Birks, H.J.B., Line, J.M., Juggins, S., Stevenson, A.C., ter Braak, C.J.F., 1990. Diatoms and pH reconstruction. Philos. Trans. R. Soc. B 327, 263-278.

Bond, G., Kromer, B., Beer, J., Muscheler, R., Evans, M. N., Showers, W., Hoffmann, S., Lotti-Bond, R., Hajdas, I., Bonani, G., 2001. Persistent solar influence on North Atlantic climate during the Holocene. Science 294, 2130-2136.

Borcard, D., Legendre, P., Drapeau, P., 1992. Partialling out the spatial component of ecological variation. Ecology 73, 1045-1055.

Buckley, B.M., Anchukaitis, K.J., Penny, D., Fletcher, R., Cook, E.R., Sano, M., Nam, L.C., Wichienkeeo, A., Minh, T.T., Hong, T.M., 2010. Climate as a contributing factor in the demise of Angkor, Cambodia. Proc. Natl. Acad. Sci. USA 107, 6748-6752.

Büntgen, U., Myglan, V.S., Charpentier, L.F., McCormick, M., Di, C.N., Sigl, M., Jungclaus, J., Wagner, S., Krusic, P.J., Esper, J., Kaplan, J.O., de Vaan, M.A.C., Luterbacher, J., Wacker, L., Tegel, W., Kirdyanov, A.V., 2016. Cooling and societal change during the Late Antique Little Ice Age from 536 to around $660 \mathrm{AD}$. Nat. Geosci. 9, 231-236.

Büntgen, U., Tegel, W., Nicolussi, K., McCormick, M., Frank, D., Trouet, V., Kaplan, J., Herzig, F., Heussner, U., Wanner, H., Luterbacher, J., Esper, J., 2011. 2500 years of European climate variability and human susceptibility. Science $331,578-582$.

Cheddadi, R., Yu, G., Guiot, J., Harrison, S.P., Prentice, I.C., 1997. The climate of Europe 6000 years 
ago. Clim. Dyn. 13, 1-9.

Chen, F.H., Xu, Q.H., Chen, J.H., Birks, H.J.B., Liu, J.B., Zhang, S.R., Jin, L.Y., An, C.B., Telford, R.J., Cao, X.Y., Wang, Z.L., Zahng, X.J., Selvaraj, K., Lü, H.Y., Li, Y.C., Zheng, Z., Wang, H.P., Zhou, A.F., Dong, G.H., Zhang, J.W., Huang, X.Z., Bloemendal, J., Rao, Z.G., 2015a. East Asian summer monsoon precipitation variability since the last deglaciation. Sci. Rep. 5, 11186.

Chen, J.H., Chen, F.H., Feng, S., Huang, W., Liu, J.B., Zhou, A.F., 2015b. Hydroclimatic changes in China and surroundings during the Medieval Climate Anomaly and Little Ice Age: spatial patterns and possible mechanisms. Quat. Sci. Rev. 107, 98-111.

Chen, L.Z., Wang, Z.W., 1999. The Impact of Human Alteration on Ecosystem Diversity. Zhejiang Science and Technology Press, Zhejiang (in Chinese).

Cheng, B., Chen, F., Zhang, J., 2013. Palaeovegetational and palaeoenvironmental changes since the last deglacial in Gonghe basin, northeast Tibetan plateau. J. Geophys. Res. 23, 136-146.

Chowdhury, P., Khan, M., Ray, P.C., 2009. Intermediate-term periodicities in sunspot areas during solar cycles 22 and 23. Mon. Not. R Astron. Soc. 392, 1159-1180.

Christiansen, B., Ljungqvist, F.C., 2012. The extra-tropical Northern Hemisphere temperature in the last two millennia: reconstructions of low-frequency variability. Clim. Past 8, 765-786.

Cook, E.R., Anchukaitis, K.J., Buckley, M., D’Arrigo, R.D., Jacoby, J.C., Wright, W.E., 2010. Asian monsoon failure and megadrought during the last millennium. Science 328, 486-489.

Cook, E.R., Seager, R., Cane, M.A., Stahle, D.W., 2007. North American drought: reconstructions, causes, and consequences. Earth-Sci. Rev. 81, 93-134.

Davis, B.A.S., Brewer, S., Stevenson, A.C., Guiot, J., Data Contributors, 2003. The temperature of 
Europe during the Holocene reconstructed from pollen data. Quat. Sci. Rev. 22, 1701-1716.

Dykoski, C.A., Edwards, R.L., Cheng, H., Yuan, D.X., Cai, Y.J., Zhang, M.L., Lin, Y.S., Qing, J.M., An, Z.S., Revenaugh, J., 2005. A high-resolution, absolute-dated Holocene and deglacial Asian monsoon record from Dongge Cave, China. Earth Planet. Sci. Lett. 233, 71-86.

Enzel, Y., Bookman, R., Sharon, D., Gvirtzman, H., Dayan, U., Ziv, B., Stein, M., 2003. Late Holocene climates of the Near East deduced from Dead Sea level variations and modern regional winter rainfall. Quat. Res. 60, 263-273.

Fang, J.Q., Xie, Z., 1994. Deforestation in preindustrial China: the Loess Plateau region as an example. Chemosphere 29, 983-999.

Feng, Z.D., An, C.B., Wang, H.B., 2006. Holocene climatic and environmental changes in the arid and semi-arid areas of China: a review. Holocene 16, 119-130.

Fleitmann, D., Burns, S. J., Mudelsee, M., Neff, U., Kramers, J., Mangini, A., Matter, A., 2003. Holocene forcing of the Indian Monsoon recorded in a stalagmite from southern Oman. Science $300,1737-1739$.

Gao, Y., Xu, S., Guo, Q., Zhang, M., 1962. Monsoon region and regional climate in China. In: Gao, Y., Xu, S. (Eds.), Some Problems of East Asian Monsoon. Science Press, Beijing, pp. 49-63 (in Chinese).

Ge, Q. S., Zheng, J. Y., Fang, X. Q., Man, Z. M., Zhang, X. Q., Zhang, P. Y., Wang, W. C., 2003. Winter half-year temperature reconstruction for the middle and lower reaches of the Yellow River and Yangtze River, China, during the past 2000 years. Holocene 13, 933-940.

Ge, Q., Hao, Z., Zheng, J., Shao, X., 2013. Temperature changes over the past $2000 \mathrm{yr}$ in China and 
comparison with the Northern Hemisphere. Clim. Past 9, 1153-1160.

Ge, Q.S., Zheng, J.Y., Hao, Z.X., Shao, X.M., Wang, W.C., Luterbacher, J., 2010. Temperature variation through 2000 years in China: An uncertainty analysis of reconstruction and regional difference. Geophys. Res. Lett. 37, L03703.

Guiot, J., Wu, H., Jiang, W.Y., Luo, Y.L., 2008. East Asian Monsoon and paleoclimatic data analysis: a vegetation point of view. Clim. Past 4, 137-145.

Haigh, J.D., 1996. The impact of solar variability on climate. Science 272, 981-984.

Haug, G.H., Günther, D., Peterson, L.C., Sigman, D.M., Hughen, K.A., Aeschliman, B., 2003. Climate and the collapse of Maya civilization. Science 299, 1731-1735.

Haug, G.H., Hughen, K.A., Sigman, D.M., Peterson, L.C., Röhl, U., 2001. Southward migration of the intertropical convergence zone through the Holocene. Science 293, 1304-1308.

Heiri, O., Brooks, S.J., Renssen, H., Bedford, A., Hazekamp, M., Ilyashuk, B., Jeffers, E.S., Lang, B., Kirilova, E., Kuiper, S., Millet, L., Samartin, S., Toth, M., Verbruggen, F., Watson, J.E., van, Asch, N., Lammertsma, E., Amon, L., Birks, H.H., Birks, H.J.B., Mortensen, M.F., Hoek, W.Z., Magyari, E., Muñoz, S.C., Seppä, H., Tinner, W., Tonkov, S., Veski, S., Lotter, A.F., 2014. Validation of climate model-inferred regional temperature change for late-glacial Europe. Nat. Commun. 5, 4914-4914.

Herzschuh, U., Kramer, A., Mischke, S., Zhang, C.J., 2009. Quantitative climate and vegetation trends since the late glacial on the northeastern Tibetan Plateau deduced from Koucha Lake pollen spectra. Quat. Res. 71, 162-171.

Hou, X., 2001. Vegetation Atlas of China. Science Press, Beijing (in Chinese). 
Huntley, B., Prentice, I.C., 1988. July temperatures in Europe from pollen data, 6000 years before present. Science 241, 687-690.

Issar, A.S., 1995. Climate change and the history of the Middle East. Am. Sci. 83, 350-355.

Jiang, W.Y., Guo, Z.T., Sun, X.J., Wu, H.B., Chu, G.Q., Yuan, B.Y., Hatté, C., Guiot, J., 2006. Reconstruction of climate and vegetation changes of Lake Bayanchagan (Inner Mongolia): Holocene variability of the East Asian monsoon. Quat. Res. 65, 411-420.

Jin, L., Schneider, B., Park, W., Latif, M., Khon, V., Zhang, X., 2014. The spatial-temporal patterns of Asian summer monsoon precipitation in response to Holocene insolation change: a model-data synthesis. Quat. Sci. Rev. 85, 47-62.

Jones, P.D., Briffa, K.R., Osborn, T.J., Lough, J.M., Ommen, T.D.v, Vinther, B.M., Luterbacher, J., Wahl, E.R., Zwiers, F.W., Mann, M.E., Schmidt, G.A., Ammann, C.M., Buckley, B.M., Cobb, K.M., Esper, J., Goosse, H., Graham, N., Jansen, E., Kiefer, T., Kull, C., Küttel, M., Mosley-Thompson, E., Overpeck, J.T., Riedwyl, N., Schulz, M., Tudhope, A.W., Villalba, R., Wanner, H., Wolff, E., Xoplaki, E., 2009. High resolution paleoclimatology of the last millennium: a review of current status and future prospects. Holocene 19, 3-49.

Juggins, S., 2007. C2 Version 1.5 User guide. Software for ecological and palaeoecological data analysis and visualisation. Newcastle University, Newcastle upon Tyne.

Kim, G.S., Choi, I.S., 1987. A preliminary study on long-term variation of unusual climate phenomena during the past 1000 years in Korea. In: D. Ye. (Ed.), The Climate of China and Global Climate. Springer, New York, pp. 30-37.

Kobashi, T., Goto-Azuma, K., Box, J.E., Gao, C.C., Nakaegawa, T., 2013. Causes of Greenland 
temperature variability over the past $4000 \mathrm{yr}$ : implications for northern hemispheric temperature changes. Clim. Past 9, 2299-2317.

Li, J.Y., Ilvonen, L., Xu, Q.H., Ni, J., Jin, L.Y., Holmström, L., Zheng, Z., Lu, H.Y., Luo, Y.L., Li, Y.C., Li, C.H., Zhang, X.J., Seppä, H., 2015a. East Asian summer monsoon precipitation variations in china over the last 9500 years: a comparison of pollen-based reconstructions and model simulations. Holocene 26, 592-602.

Li, J.Y., Xu, Q.H., Zhuo, Z., Lu, H.Y., Luo, Y.L., Li, Y.C., Li, C.H., Seppä, H., 2015b. Assessing the importance of climate variables for the spatial distribution of modern pollen data in China. Quat. Res. 83, 287-297.

Li, J.Y., Zhao, Y., Xu, Q.H., Zheng, Z., Lu, H.Y., Luo, Y.L., Li, Y.C., Li, C.H., Seppä, H., 2014 Human influence as a potential source of bias in pollen-based quantitative climate reconstructions. Quat. Sci. Rev. 99, 112-121.

Li, K.J., Su, T.W., Liang, H.F., 1996. Sunspot unit areas: a new parameter describing the long-term solar activity. Chin. Sci. Bull. 49, 2511-2516.

Li, Y.C., Xu, Q.H., Liu, J.S., Yang, X.L., Nakagawa, T., 2007. A transfer-function model developed from an extensive surface-pollen data set in northern China and its potential for palaeoclimate reconstructions. Holocene 17, 897-905.

Liu, J., Wang, B., Wang, H., Kuang, X., Ti, R., 2011. Forced response of the East Asian summer rainfall over the past millennium: results from a coupled model simulation. Clim. Dyn. 36, $323-336$.

Liu, J.B., Chen, J.H., Zhang, X.J., Li, Y., Rao, Z.G., Chen, F.H., 2015. Holocene East Asian summer 
monsoon records in northern China and their inconsistency with Chinese stalagmite $\delta^{18} \mathrm{O}$ records. Earth Sci. Rev. 148, 194-208.

Liu, X.Q., Shen, J., Wang, S.M., Yang, X.D., Tong, G.B., Zhang, E.L., 2002. A 16000-year pollen record of Qinghai Lake and its Paleoclimate and Paleoenvironment. Chin. Sci. Bull. 47, 1931-1937.

Liu, Y., An, Z. S., Ma, H. Z., Cai, Q. F., Liu, Z. Y., Kutzbach, J.K., Shi, J. F., Song, H. M., Sun, J. Y., Yi, L., Li, Q., Yang, Y. K., Wang, L., 2006. Precipitation variation in the northeastern Tibetan Plateau recorded by the tree rings since $850 \mathrm{AD}$ and its relevance to the Northern Hemisphere temperature. Sci. China Ser. D 49, 408-420.

Liu, Y., Wu, X., Leavitt, S.W., Hughes, M.K., 1996. Stable carbon isotope in tree rings from Huangling, China and climatic variation. Sci. China Ser. D 39, 152-161.

Ljungqvist, F.C., 2010. A new reconstruction of temperature variability in the extra-tropical northern hemisphere during the last two millennia. Geography Geogr. Ann. A 92, 339-351.

Lorenz, S.J., Lohmann, G., 2004. Acceleration technique for Milankovitch type forcing in a coupled atmosphere-ocean circulation model: method and application for the Holocene. Clim. Dyn. 23: $727-743$.

Madec, 2008. NEMO Reference Manual, Ocean Dynamics Component: NEMO-OPA. Preliminary version. Note Pole Model. 27. Inst. Pierre Simon Laplace, Paris.

Mann, M.E., Woodruff, J.D., Donnelly, J.P., Zhang, Z., 2009. Atlantic hurricanes and climate over the past 1,500 years. Nature $460,880-883$.

Mauri, A., Davis, B.A.S., Collins, P.M., Kaplan, J.O., 2015. The climate of Europe during the 
Holocene: a gridded pollen-based reconstruction and its multi-proxy evaluation. Quat. Sci. Rev. $112,109-127$.

Olsen, J., Anderson, N.J., Knudsen, M.F., 2012. Variability of the north Atlantic oscillation over the past 5200 years. Nat. Geosci. 5, 808-812.

Park, W., Keenlyside, N., Latif, M., Stroeh, A., Redler, R., Roeckner, E., Madec, G., 2009. Tropical Pacific climate and its response to global warming in the Kiel Climate Model. J. Clim. 22, 71-92.

Peng, Y., Xiao, J., Nakamura, T., Liu, B., Inouchi, Y., 2005. Holocene East Asian monsoonal precipitation pattern revealed by grain size distribution of core sediments of Daihai Lake in Inner Mongolia of north-central China. Earth Planet. Sci. Lett. 233, 467-479.

Peyron, O., Goring, S., Dormoy, I., Kotthoff, U., Pross, J., de Beaulieu, J.L., DrescherSchneider, R., Vanniere, B., Magny, M., 2011. Holocene seasonality changes in the central Mediterranean region reconstructed from the pollen sequences of Lake Accesa (Italy) and Tenaghi Philippon (Greece). Holocene 21, 131-146.

Prentice, I.C., 1980. Multidimensional scaling as a research tool in Quaternary palynology: a review of theory and methods. Rev. Palaeobot. Palyno. 31, 71-104.

Ran, M., Feng, Z., 2013. Holocene moisture variations across China and driving mechanisms: a synthesis of climatic records. Quat. Int. 313, 179-193.

Reimer, P.J., Baillie, M.G.L., Bard, E., Bayliss, A., Beck, J.W., Blackwell, P.G., Bronk, Ra.C., Buck, C.E., Burr, G.S., Edwards, R.L., Friedrich, M., Grootes, P.M., Guilderson, T.P., Hajdas, I., Heaton, T.J., Hogg, A.G., Hughen, K.A., Kaiser, K.F., Kromer, B., McCormac, F.G., Manning, 
S.W., Reimer, R.W., Richards, D.A., Southon, J.R., Talamo, S., Turney, C.S.M., van der Plicht, J., Weyhenmeyer, C.E., 2009. IntCal09 and Marine09 radiocarbon age calibration curves, 0-50,000 years cal BP. Radiocarbon 51, 1111-1150.

Reimer, P.J., Baillie, M.G.L., Bard, E., Bayliss, A., Beck, J.W., Bertrand, C.J.H., Blackwell, P.G., Buck, C.E., Burr, G.S., Cutler, K.B., Damon, P.E., Edwards, R.L., Fairbanks, R.G., Friedrich, M., Guilderson, T.P., Hogg, A.G., Hughen, K.A., Kromer, B., McCormac, F.G., Manning, S.W., Ramsey, C.B., Reimer, R.W., Remmele, S., Southon, J.R., Stuiver, M., Talamo, S., Taylor, F.W., van der Plicht, J., 2004. Intcal04 terrestrial radiocarbon age calibration, 0-26 cal kys BP. Radiocarbon 46, 1029-1058.

Reimer, P.J., Bard, E., Bayliss, A., Beck, J.W., Blackwell, P.G., Ramsey, B.C., Grootes, P.M., Guilderson, T.P., Haflidason, H., Hajdas, I., Hatte, C., Heaton, T.J., Hoffmann, D.L., Hogg, A.G., Hughen, K.A., Kaiser, K.F., Kromer, B., Manning, S.W., Niu, M., Reimer, R.W., Richards, D.A., Scott, E.M., Southon, J.R., Staff, R.A., Turney, C.S.M., van der Plicht, J., 2013. IntCal13 and Marine13 radiocarbon Age calibration curves 0-50,000 years cal BP. Radiocarbon $55,1869-1887$.

Ren, G.Y., 2000. Decline of the mid- to late Holocene forests in China: climatic change or human impact? J. Quat. Sci. 15, 273-281.

Ren, G.Y., Beug, H.J., 2002. Mapping Holocene pollen data and vegetation of China. Quat. Sci. Rev. $21,1397-1398$.

Renssen, H., Seppä, H., Heiri, O., Roche, D. M., Goosse, H., Fichefet, T., 2009. The spatial and temporal complexity of the Holocene thermal maximum. Nat. Geosci. 2, 411-414. 
Roeckner, E., Bäuml, G., Bonaventura, L., Brokopf, R., Esch, M., Giorgetta, M., Hagemann, S., Kirchner, I., Kornblueh, L., Manzini, E., Rhodin, A., Schlese, U., Schulzweida, U., Tompkins, A., 2003. The Atmospheric General Circulation Model ECHAM5. Part I: Model Description, Rep. 349. Max Planck Institut für Meteorologie, Hamburg, Germany, pp. 127.

Salonen, J.S., Luoto, M., Alenius, T., Heikkilä, M., Seppä, H., Telford, R.J., Birks, H.J.B., 2014. Reconstructing palaeoclimatic variables from fossil pollen using boosted regression trees: comparison and synthesis with other quantitative reconstruction methods. Quat. Sci. Rev. 88, 69-81.

Schulz, M., Mudelsee, M., 2002. REDFIT: estimating red-noise spectra directly from unevenly spaced paleoclimatic time series. Comput. Geosci. 28, 421-426.

Seppä, H., Birks, H.J.B., Odland, A., Poska, A., Veski, S., 2004. A modern pollen-climate calibration set from northern Europe: developing and testing a tool for palaeoclimatological reconstructions. J. Biogeogr. 31, 251-267.

Seppä, H., Bjune, A.E., Telford, R.J., Birks, H.J.B., Veski, S., 2009. Last nine-thousand years of temperature variability in Northern Europe. Clim. Past 5, 523-535.

Shen, J., Liu, X.Q., Wang, S.M., Matsumoto, R., 2005. Palaeoclimatic changes in the Qinghai Lake area during the last 18,000 years. Quat. Int. 136, 131-140.

Shi, N.H., 1991. Vegetation distribution and changes during Chinese historical period. Chin. Hist. Geogr. 3, 43-73 (in Chinese).

Shindell, D., Rind, D., Balachandran, N., Lean, J., Lonergan, P., 1999. Solar cycle variability, ozone, and climate. Science 284, 305-308. 
Sone, T., Kano, A., Okumura, T., Kashiwagi, K., Hori, M., Jiang, X., Shen, C.C., 2013. Holocene stalagmite oxygen isotopic record from the Japan sea side of the Japanese islands, as a new proxy of the East Asian winter monsoon. Quat. Sci. Rev. 75, 150-160.

Stebich, M., Rehfeld, K., Schlütz, F., Tarasov, P.E., Liu, J., Mingram, J., 2015. Holocene vegetation and climate dynamics of NE China based on the pollen record from Sihailongwan Maar lake. Quat. Sci. Rev. 124, 275-289.

Sun, A.Z., Feng, Z.D., 2013. Holocene climatic reconstructions from the fossil pollen record at Qigai Nuur in the southern Mongolian Plateau. Holocene 23, 1391-1402.

Tan, L., Cai, Y., An, Z., Cheng, H., Shen, C.C., Breitenbach, S.F., Cao, Y., Edwards, R.L., Zhang, H., Du, Y., 2015. A Chinese cave links climate change, social impacts, and human adaptation over the last 500 years. Sci. Rep. 5, 104-104.

Tan, L., Cai, Y., An, Z., Edwards, R.L., Cheng, H., Shen, C., Zhang, H., 2010. Centennial- to decadal-scale monsoon precipitation variability in the semi-humid region, northern china during the last 1860 years: records from stalagmites in Huangye Cave. Holocene 21, 287-296.

Tan, L.C., Cai, Y.J., An, Z.S., Liang, Y., Zhang, H.W., Qin, S.J., 2011. Climate patterns in north central China during the last $1800 \mathrm{yr}$ and their possible driving force. Clim. Past. 7, 685-692.

Tan, M., Hou, J.Z., Qin, X.G., Zhang, H.C., Li, T.Y., 2003. Cyclic rapid warming on centennial scale revealed by a 2650 -year stalagmite record of warm season temperature. Geophys. Res. Lett. 30, $1617-1621$.

ter Braak, C.J.F., Juggins, S., 1993. Weighted averaging partial least squares regression (WA-PLS): an improved method for reconstructing environmental variables from species assemblages. 
Hydrobiologia 269, 485-502.

ter Braak, C.J.F., Šmilauer, P., 2002. CANOCO Reference Manual and Canodraw for Windows User's Guide: Software for Canonical Community Ordination (version 4.5). Microcomputer Power, Ithaca, New York.

ter Braak, C.J.F., Šmilauer, P., 2012. Canoco Reference Manual and User's Guide: Software for Ordination, version 5.0. Microcomputer Power, Ithaca, New York.

Tinsley, B.A., 2000. Influence of solar wind on the global electric circuit, and inferred effects on cloud microphysics, temperature, and dynamics in the troposphere. Space Sci. Rev. 94, $231-258$.

Trouet, V., Esper, J., Graham, N.E., Baker, A., Scourse, J.D., Frank, D.C., 2009. Persistent positive north Atlantic oscillation mode dominated the medieval climate anomaly. Science 324, 78-80.

Valcke, S., 2006. OASIS3 User Guide, PRISM Tech. Rep. 3. Partnership for Res. Infrastructures in Earth Syst. Model, Toulouse, France, pp. 64.

Viau, A.E., Gajewski, K., Sawada, M.C., Fines, P., 2006. Millenial-scale temperature variability in North America during the Holocene. J. Geophys. Res. 111, D09102.

Vieira, L.E.A., Solanki, S.K., Krivova, N.A., Usoskin, I., 2011. Evolution of the solar irradiance during the Holocene. Astron. Astrophys. Rev. 531, A6.

Wang, S.W., Wen, X.Y., Luo, Y., Dong, W.J., Zhao, Z.C., Yang, B., 2007. Reconstruction of temperature series of China for the last 1000 years. Chin. Sci. Bull. 52, 3272-3280.

Wang, Y.J., Cheng, H., Edwards, R.L., He, Y.Q., Kong, X.G., An, Z.S., Wu, J.Y., Kelly, M.J., Dykoski, C.A., Li, X.D., 2005. The Holocene Asian Monsoon: links to solar changes and North 
Atlantic climate. Science 308, 854-857.

Wanner, H., Beer, J., Butikofer, J., Crowley, T. J., Cubasch, U., Fluckiger, J., Goosse, H., Grosjean, M., Joos, F., Kaplan, J. O., Kuttel, M., Muller, S. A., Prentice, I. C., Solomina, O., Stocker, T. F., Tarasov, P., Wagner, M., and Widmann, M., 2008. Mid-to Late Holocene climate change: an overview. Quat. Sci. Rev. 27, 1791-1828.

Weiss, H., Bradley, R.S., 2001. What drives societal collapse? Science 291, 609-610.

Wilson, R.M., Hathaway, D.H., Reichmann, E.J., 1996. On the behavior of the sunspot cycle near minimum. J. Geophys. Res. 101, 19967-19972.

Wu, B., Wang, J., 2002. Winter Arctic Oscillation, Siberian High, and East Asian Winter Monsoon. Geophys. Res. Lett. 29, 1897.

Xu, D., Lu, H., Chu, G., Wu, N., Shen, C., Wang, C., Mao, L., 2014. 500-year climate cycles stacking of recent centennial warming documented in an East Asian pollen record. Sci. Rep. 4, 204-208.

Xu, Q.H., Xiao, J.L., Li, Y.C., Tian, F., Nakagawa, T., 2010. Pollen-based quantitative reconstruction of Holocene climate changes in the Daihai Lake area, Inner Mongolia, China. J. Clim. 23, $2856-2868$.

Yang, B., Braeuning, A., Johnson, K.R., Shi, Y.F., 2002. General characteristics of temperature variation in China during the last two millennia. Geophys. Res. Lett. 29, 1324.

Yang, X.L., Liu, J.B., Liang, F.Y., Yuan, D.X., Yang, Y., Chen, F.H., 2014. Holocene stalagmite $\delta^{18}$ O records in the East Asian monsoon region and their correlation with those in the Indian monsoon region. Holocene 24, 1657-1664. 
Zhang, D.D., Brecke, P., Lee, H.F., He, Y.Q., Zhang, J., 2007. Global climate change, war, and population decline in recent human history. Proc. Natl. Acad. Sci. USA 104, 19214-19219.

Zhang, D.D., Lee, H. F., Wang, C., Li, B., Zhang, J., Pei, Q., Chen, J., 2011. Climate change and large-scale human population collapses in the pre-industrial era. Global Ecol. Biogeogr. 20, $520-531$.

Zhang, D.D., Lee, H.F., Wang, C., Li, B., Pei, Q., Zhang, J., An, Y., 2011. The causality analysis of climate change and large-scale human crisis. Proc. Natl. Acad. Sci. USA 108, 17296-17301.

Zhang, D.D., Pei, Q., Lee, H.F., Zhang, J., Chang, C.Q., Li, B., Li, J., Zhang, X., 2014. The pulse of imperial China: a quantitative analysis of long-term geopolitical and climatic cycles. Global. Ecol. Biogeogr. 24, 87-96.

Zhang, D.E., Li, H.C., Ku, T.L., Lu, L., 2010. On linking climate to Chinese dynastic change: Spatial and temporal variations of monsoonal rain. Chin. Sci. Bull. 55, 77-83.

Zhang, P., Cheng, H., Edwards, R.L., Chen, F., Wang, Y., Yang, X., Liu, J., Tan, M., Wang, X., Liu, J., An, C., Dai, Z., Zhou, J., Zhang, D., Jia, J., Jin, L., Johnson, K.R., 2008. A test of climate, sun, and culture relationships from an 1810-year Chinese cave record. Science 322, 940-942.

Zhang, Z., 2006. Introduction to Chinese Archaeology. Nanjing: Nanjing University Press, pp. 96 (in Chinese).

Zhao, P., Zhu, Y., Zhang, R., 2007. An Asian-Pacific teleconnection in summer tropospheric temperature and associated Asian climate variability. Clim. Dyn. 29, 293-303.

Zhao, W., Xie, S., 1988. Population History of China. People's Press, Beijing (in Chinese).

Zhao, X.H., Feng, X.S, 2014. Periodicities of solar activity and the surface temperature variation of 
the Earth and their correlations. Chin. Sci. Bull. 59, 1284-1292.

Zhao, Y., Xu, Q.H., Huang, X.Z., Guo, X.L., Tao, S.C., 2009a. Difference of modern pollen assemblages from lake sediments and surface soils in arid and semi-arid China and their significance for pollen-based quantitative climate reconstruction. Rev. Palaeobot. Palyno. 156, $519-524$.

Zhao, Y., Yu, Z., Chen, F., Zhang, J., Yang, B., 2009b. Vegetation response to Holocene climate change in monsoon-influenced region of China. Earth-Sci. Rev. 97, 242-256.

Zheng, J.Y., Wang, W.C., Ge, Q.S., Man, Z.M., Zhang, P.Y., 2006. Precipitation variability and extreme events in eastern China during the past 1500 years. Terr. Atmos. Ocean Sci. 17, $579-592$.

Zheng, Z., Wei, J.H., Huang, K.Y., Xu, Q.H., Lu, H.Y., Tarasov, P., Luo, C.X., Beaudouin, C., Deng, Y., Pan, A.D., Zheng, Y.W., Luo, Y.L., Nakagawa, T., Li, C.H., Yang, S.X., Peng, H.H., Cheddadi, R., 2014. East Asian pollen database: modern pollen distribution and its quantitative relationship with vegetation and climate. J. Biogeogr. 41, 1819-1832.

Zhou, X., Zhao, P., Liu, G., 2009. Asian-Pacific Oscillation index and variation of East Asian summer monsoon over the past millennium. Chin. Sci. Bull. 54, 3768-3771.

Zhu, S., 1992. Vegetation changes of Northeast China during historical period. Chin. Hist. Geogr. 4, 105-119 (in Chinese).

Zhu, S.G., 1994. Changes of the vegetation in the North China Plain during historical period. J. Shaanxi Norm. Univ. 22, 79-85 (in Chinese).

\section{Figure captions}


Figure 1. Locations of monsoonal northern China and fossil pollen records from 11 lakes (see Table S1 for details and references).

Figure 2. Comparison of pollen-based and KCM-simulated PANN records for monsoonal northern China (NC) with other moisture records from the East Asian monsoon-influenced region: (a) the detrended, 15-point smoothed pollen-based PANN anomaly $( \pm 21 \mathrm{~mm})$ for $\mathrm{NC}$; (b) the 15 -point smoothed KCM-simulated PANN anomaly (mm) for $\mathrm{NC}\left(100-130{ }^{\circ} \mathrm{E}\right.$ and $\left.35-50{ }^{\circ} \mathrm{N}\right)$; (c) the synthesized precipitation index for north-central China (Tan et al., 2011); the $\delta^{18} \mathrm{O}$ records from (d) Wanxiang Cave (Zhang et al., 2008) and (e) Huangye (Tan et al., 2010) Cave on the western Loess Plateau; (f) the regional dry-wet index based on historical documents in the northern China Plain (NC) (Zheng et al., 2006); (g) the coupled ECHO-G simulated precipitation for northern China during summertime from May to August (MJJA) (Liu et al., 2011); (h) the drought index based on historical records from Korea (Kim and Choi, 1987); and (i) the $\delta^{18} \mathrm{O}$ record from Fukugaguchi Cave in Japan (Sone et al., 2013). The pink bands depict wet periods, while the gray bands indicate dry periods.

Figure 3. Comparison of pollen-inferred TANN record with other related climatic records: (a) the detrended, 15-point smoothed pollen-based TANN anomaly (TA, $\pm 0.3{ }^{\circ} \mathrm{C}$ ) for $\mathrm{NC}$; (b) the composited temperature anomaly (TA) for the entire China (Ge et al., 2013); (c) the winter half-year temperature anomaly (TA) for central eastern (EC) China (Ge et al., 2003); (d) the temperature anomaly (TA) of monsoonal warm-season from May to August from Shihua Cave in NC (Tan et al., 2003); (e-g) the three integrated temperature anomaly series (TA-1-3) for northern Hemisphere (NH) (Ljungqvist, 2010; Christiansen and Ljungqvist, 2012; Kobashi et al., 2013); (h) the Total Solar 
Irradiance record (TSI; Vieira et al., 2011); (i) the Asian Pacific Oscillation index (APO; Zhou et al., 2009); (j) the Intertropical Convergence Zone index (ITCZ; Haug et al., 2001); (k) the North Atlantic Oscillation index (NAO; Trouet et al., 2009; Olsen et al., 2012); and (1) the Ice-Rafted Debris record (IRD; Bond et al., 2001) from the North Atlantic Ocean. The pink bands represent warm periods, whereas the gray bands indicate cold periods.

Figure 4. Results of spectral analyses for pollen-based composited (a) PANN and (b) TANN records in monsoonal northern China over the last 2200 years.

Figure 5. Comparison of pollen-based reconstructions for both PANN and TANN with 17 Chinese numerical historical records from the Han to Qing Dynasty (see Table S3 for details and references): (a) the detrended and 15-point smoothed pollen-based precipitation anomaly (mm), (b) the detrended and 15-point smoothed pollen-based temperature anomaly $\left({ }^{\circ} \mathrm{C}\right),(\mathrm{c})$ economic level, (d) grain yield grade, (e) grain price index, (f) fiscal grade, (g) agriculturalist policy territory, (h) extreme flood years, (i) extreme drought years, (j) freeze disaster frequency, (k) sand-dust event frequency, (l) famine index, (m) locust frequency, (n) epidemic disaster frequency, (o) peasant uprising frequency, (p) number of wars, (q) number of southward nomadic migrations, (r) farming-pastoral boundary, and (s) number of estimated human population. 5D \& 10K represents the period of Five Dynasties and Ten Kingdoms in China. The three gray bands indicate the time intervals of Medieval Climate Anomaly (MCA), Little Ice Age (LIA), and Current Warm Period (CWP), respectively.

Figure 6. Percentage of variation (\%) in 17 numerical historical indexes (see Table S3 for details and references) accounted for independently by PANN or TANN and their joint effects. RDA triplot indicates the correlations of the 17 numerical historical indexes with PANN and TANN. The Chinese 
historical dataset consists of economic level (EL), grain yield grade (GY), grain price index (GPI), fiscal grade (FG), agriculturalist policy territory (AT), extreme flood years (EF), extreme drought years (ED), freeze disaster frequency (FD), sand-dust event frequency (SD), famine index (FI), locust frequency (LF), epidemic disaster frequency (EPD), peasant uprising frequency (PUF), number of wars (NW), number of southward nomadic migrations (SNW), farming-pastoral boundary (FPB), and number of estimated human population (HP). 


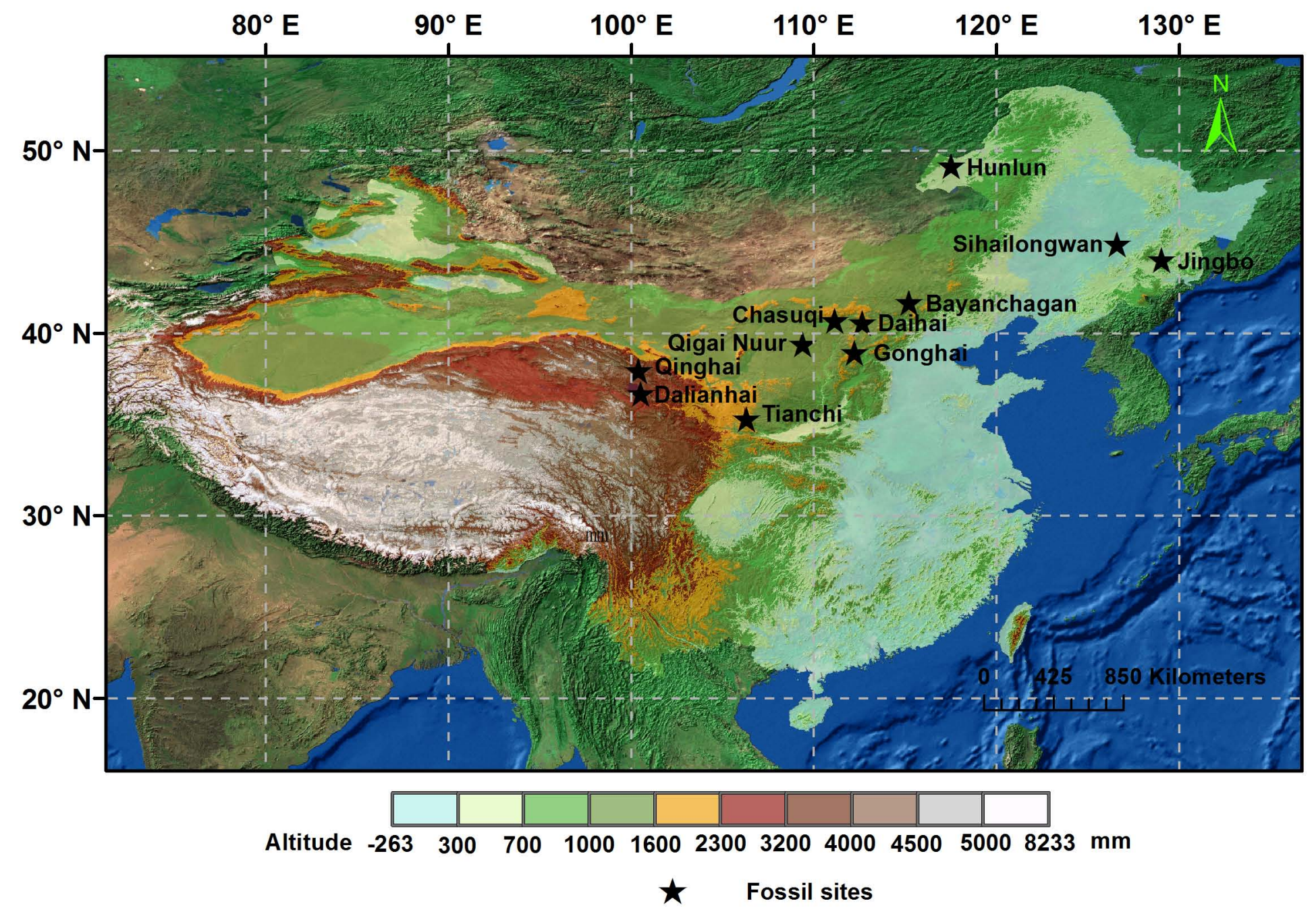




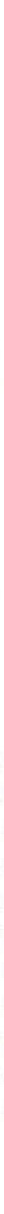




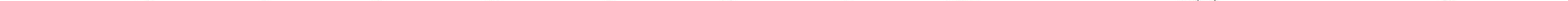






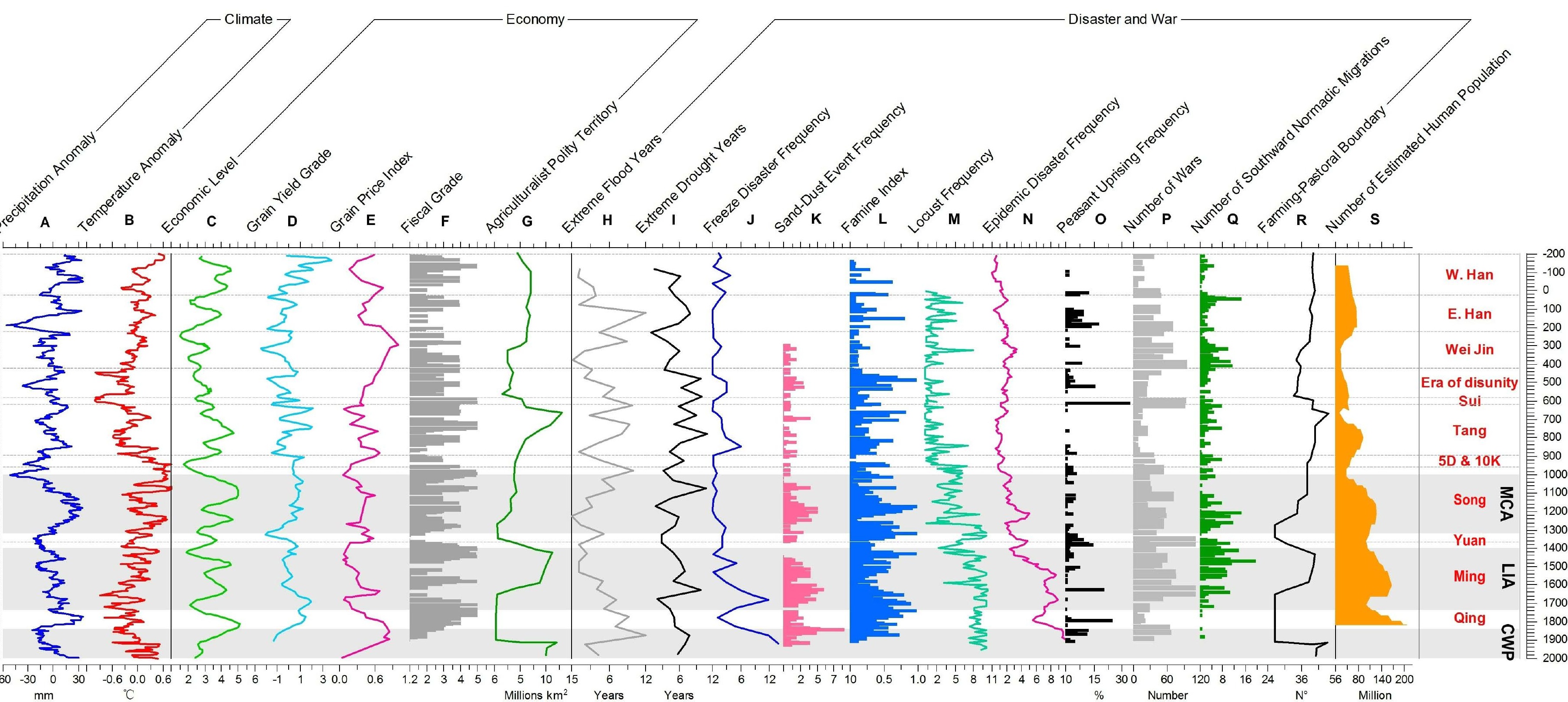




\section{Variation partioning}

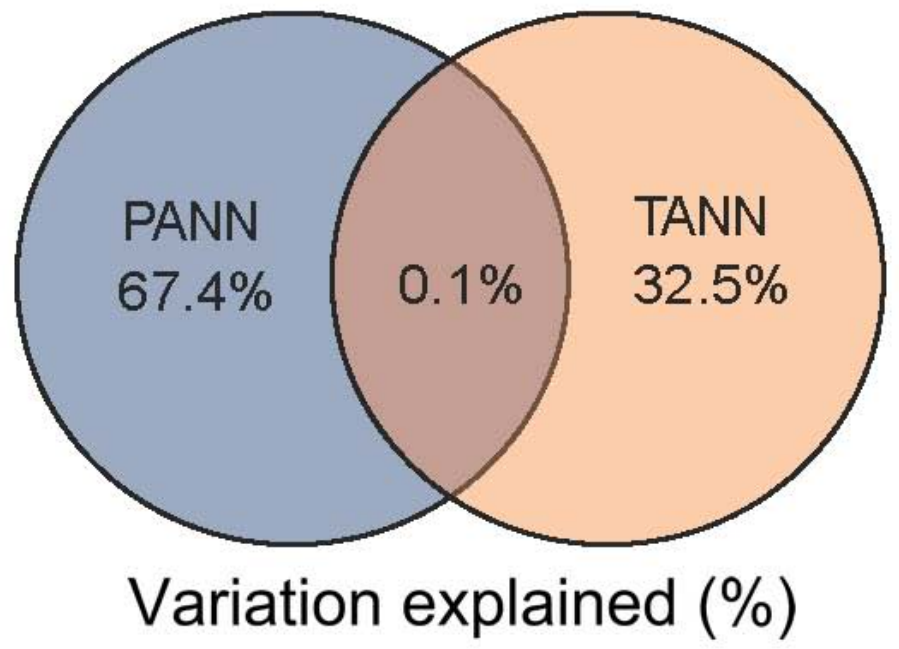

RDA

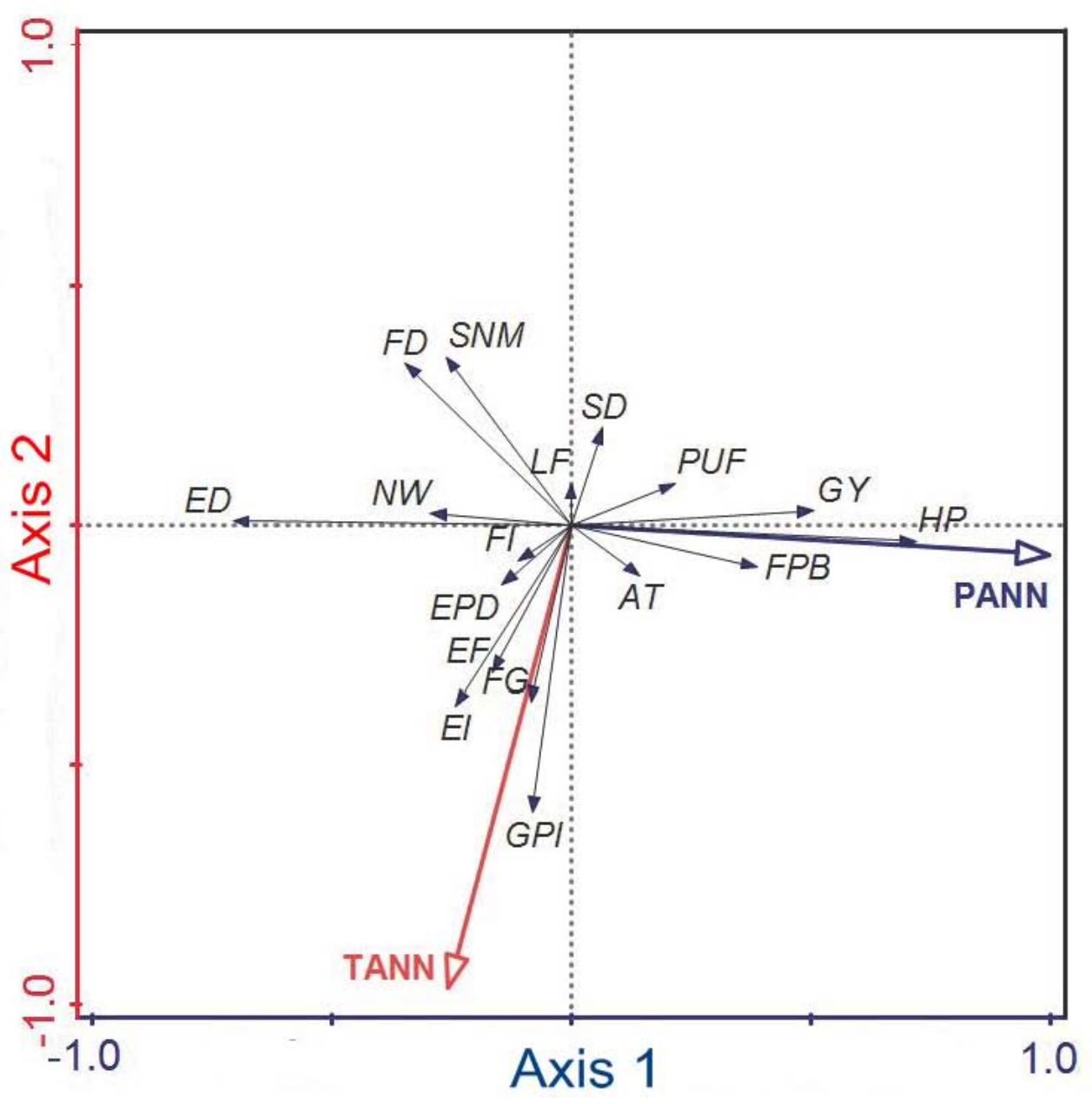

